\title{
A Natural Phosphate Electrode Modified with Antibiotic for the Detection of Bacteria
}

\author{
Bertrand OFAK ${ }^{1,2}$, Bea $B^{2}$, Belkhouya $\mathbf{N}^{1}$ and Chtaini $A^{1 *}$
}

${ }^{1}$ Team Molecular Electrochemistry and Inorganic Materials, Faculty of Science and Technology of Beni Mellal, University Sultan Moulay Slimane, Morocco ${ }^{2}$ Laboratory of Physical Chemistry, University of Felix Houphouet Boigny Cocody, Ivory Coast

\begin{abstract}
A natural phosphate electrode modified with antibiotic (amoxivillin) was employed for the detection and quantification of Staphylococcus aureus from aqueous solutions. The new electrode (AMX-NPE) revealed interesting electroanalytical detection of Staphylococcus aureus based on the adsorption of these bacteria onto antibiotic under open circuit conditions. The bacteria redox peaks were operated by square wave voltammetry in $0.1 \mathrm{~mol} / \mathrm{L} \mathrm{NaCl}$ solution. The response depends on the concentration of bacteria in the bulk solution as well as the parameters involved in the preconcentration, $\mathrm{pH}$ and the measurement steps.
\end{abstract}

Keywords: Modified electrode; SWV; CV; Bacteria; Biosensor

\section{Introduction}

The micro-organisms form integral part of ecosystems. Their presence is sometimes essential to the renewal or the maintenance of the environment. On the other hand, it Manis in permanent fight counters many viruses and bacteria pathogenic, likely to cause diseases. For several centuries, discoveries have allowed great progress of the antimicrobic fight, as well in the comprehension of the microbes as in medical research. The amoxicillin is one antibiotic $\beta$-lactamine bactericide of the family of aminopenicillins indicated in the treatment of infections bacterial with sensitive germs. It is in Alexander Flemming that one allots the discovery of antibiotics of the family of the $\beta$ lacatmines in 1928 [1]. The antimicrobic fight by the antibiotic catch becomes extensive and does not remain without consequence on the populations. A study published in 2011 indeed revealed that and a too great consumption of antibiotics during childhood could be dangerous for health [2]. The author of this study, PrBlaser established the link between the antibiotic abuse and the increase in chronic diseases like asthma, the obesity or the diabetes of the type 1 (insulino-dependent) in the children. More recently, in 2012, a study led to the NYU Medical Langone Center and University School of Medicine evaluated the use of antibiotics in 11532 children born in the United Kingdom, in 1991 and 1992 [3]. The researchers followed their health over 3 periods, of the birth in 5 months, 6 months in 14 month and 15 to 23 month like their weight. The results showed that at the 3 years age, the children treated with antibiotics between 0 and 6 months present an increased risk of $22 \%$ of overweight, and that independently of their diet, their physical activity and heredity. Another study of 2010 showed that the antibiotic catch before the 6 months age also increases the risk of asthma and allergy of $52 \%$ to the 6 years age [4]. According to another study, the children who the most consumed antibiotics during their first year of life have an increased risk of $41 \%$ to develop eczema [5]. A study was undertaken near more than 2000 adults suffering from a respiratory infection with complications; a greater number of patients under antibiotics suffered from symptoms like nauseas, an eruption of buttons or diarrhea [6]. In front of all these report it returns to us to find measurements preventive in order to avoid the abusive antibiotic consumption. The goal of this work is to work out an electrochemical biosensor likely to detect the presence of Staphylococcus aureus in an aqueous medium.

\section{Material and Methods}

\section{Reagent}

All solutions were prepared in double distilled water. The natural phosphate (NP) used in this work was obtained in the area of Khouribga (Morocco) [7]. Before the use, this material was calcined with $900^{\circ} \mathrm{C}$ during 1 hour.

The treated NP has the following chemical composition [8]: $\mathrm{CaO}$ (54,12\%), $\mathrm{P}_{2} \mathrm{O}_{5}(34,24 \%), \mathrm{F}^{-}(3,37 \%), \mathrm{SiO}_{2}(2,42 \%), \mathrm{SO}_{3}(2,21 \%), \mathrm{CO}_{2}$ (1,13\%), $\mathrm{Na}_{2} \mathrm{O}(0,92 \%), \mathrm{MgO}(0,68 \%), \mathrm{Al}_{2} \mathrm{O}_{3}(0,46 \%), \mathrm{Fe}_{2} \mathrm{O}_{3}(0,36 \%)$, $\mathrm{K}_{2} \mathrm{O}(0,04 \%)$ and several metals in the range of the part per million.

The bacterial strain used in this study was Staphylococcus aureus ATCC 25923. The strain was cultured in Luria Burtani broth at $37^{\circ} \mathrm{C}$ for $24 \mathrm{~h}$ after culture; the cells were harvested by centrifugation for 15 min at $8400 \mathrm{xg}$ and were washed twice with and resuspended in $\mathrm{KNO}_{3}$ solution with ionic strength $0.1 \mathrm{M}$. The physicochemical properties of this strain were measured by contact angle measurements.

Provisions were made for oxygen removal by bubbling the solution with azotes gas for about 5 min then the solution was blanketed with azotes gas while the experiment was in progress. For reproducible results, a fresh solution was made for each experiment.

\section{Instrumental}

Voltammetric experiments were performed using a voltalab potentiostat (model PGSTAT100, Eco Chemie B.V. Utrecht, The Netherlands) has driven by the general purpose electrochemical systems data processing software (voltalab master 4 software) run under windows 2007 . The three electrode system consisted of a chemically modified natural phosphate paste electrode as the working electrode

*Corresponding author: Abdelilah Chtaini, Team Molecular Electrochemistry and Inorganic Materials, Faculty of Science and Technology of Beni Mellal, University Sultan Moulay Slimane, Morocco, Tel: 212661118521; E-mail: a.chtaini@usms.ma

Received March 06, 2016; Accepted March 14, 2016; Published March 24, 2016

Citation: Bertrand OFAK, Bea B, Belkhouya N, Chtaini A (2016) A Natural Phosphate Electrode Modified with Antibiotic for the Detection of Bacteria. J Biosens Bioelectron 7: 202. doi:10.4172/2155-6210.1000202

Copyright: ( 2016 Bertrand OFAK, et al. This is an open-access article distributed under the terms of the Creative Commons Attribution License, which permits unrestricted use, distribution, and reproduction in any medium, provided the original author and source are credited. 
a saturated calomel electrode (SCE) serving as reference electrode and platinum as an auxiliary electrode.

\section{Electrodes}

The working natural phosphate paste electrode was prepared by mixing appropriate weight of natural phosphate powder with paraffin oil. The whole cell modified natural phosphate paste was subsequently packed firmly into the electrode cavity $\left(0.1256 \mathrm{~cm}^{2}\right)$ and polished to a smooth shiny finish by gently rubbing over an ordinary weighing paper. Electrical contact was established with a bar of carbon. Amoxilmodified natural phosphate paste electrodes (AMX-NPE) were prepared by immobilizing the Amoxicillin system by soaking the preformed natural phosphate paste electrode in a solution containing the Amoxicillin solution. The effect of the contact time (CT) of the natural phosphate paste electrode with the Amoxicillin solution (10 g. $\mathrm{L}^{-1}$ ) was studied.

\section{Analytical procedure}

The modified natural phosphate paste electrode was immersed in a cell containing bacteria sample to get a chemical accumulation. Meanwhile the solution was rotated about $600 \mathrm{rpm}$ at open circuit. After a desired contact time the electrode was removed from the preconcentration cell, rinsed with DW and placed in the measurement cell containing the supporting electrolyte $\left(1.0 \mathrm{~mol} \mathrm{~L}^{-1} \mathrm{NaCl}\right)$. The solution was deaerated with nitrogen for $10 \mathrm{~min}$. The voltammetric curve was recorded. The same procedure was carried out in sample analysis and all electrochemical experiments were carried out at room temperature. The square wave voltammograms were recorded in different bacteria concentrations using $5 \mathrm{mV}$ of the pulse amplitude, step potential $50 \mathrm{mV}$ and the duration time is $2 \mathrm{~s}$ at scan rate $1 \mathrm{mVs}^{-1}$.

\section{Results}

Preliminary experiments were carried out to study the electrochemical behavior of the electrode of rock phosphate (NPE) and AMX-NPE. The electrodes were characterized in a cell containing a $\mathrm{NaCl}$ solution with $0.1 \mathrm{M}$ in order to compare their voltammogramms (Figure 1). We note that the form of the voltammogramms changed and that is due to the modification of the surface of the electrode by the amoxicillin.

- We find that the current densities increase dramatically when the preconcentration time of amoxicillin to the natural phosphate electrode surface is $10 \mathrm{~min}$.

- After 20 min of preconcentration the current densities drop rapidly. Probably, the antibiotic molecules that are absorbed on the first layer of the film formed by amoxicillin, lead to the formation of an insulating polymer.

Hence, all subsequent experiments were carried out in $10 \mathrm{~min}$ of preconcentration (Figure 1).

The dependence of the peak current response on the amoxicillin loading in the natural paste at $\mathrm{pH} 7.42$ was performed in $0.1 \mathrm{~mol} \mathrm{~L}^{-1}$ $\mathrm{NaCl}$ containing bacteria (Figure 2). The best response is obtained when the concentration of amoxicillin solution is about $30 \mathrm{~g} / \mathrm{L}$.

The increase in the electro activity could be explained by the following mechanism $[9,10]$ (Figure 3):

In order to obtain an analytical curve for the developed sensor, we carried out square wave voltammograms for electrochemical response of bacteria at different $\mathrm{OD}$ values in $0.1 \mathrm{~mol} \mathrm{~L}^{-1} \mathrm{NaCl}$. Under optimized

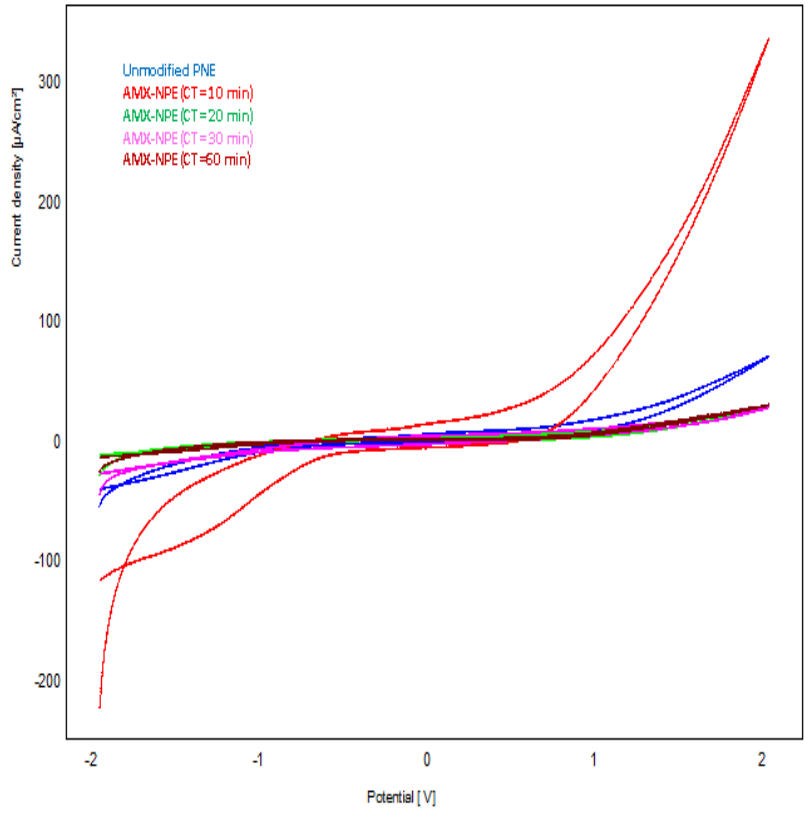

Figure 1: Voltammetric curves recorded at AMX-NPE, scan rate: $100 \mathrm{mV} \mathrm{s}^{-1}$ supporting electrolyte $0.1 \mathrm{M} \mathrm{NaCl}(\mathrm{pH} 7.42)$.

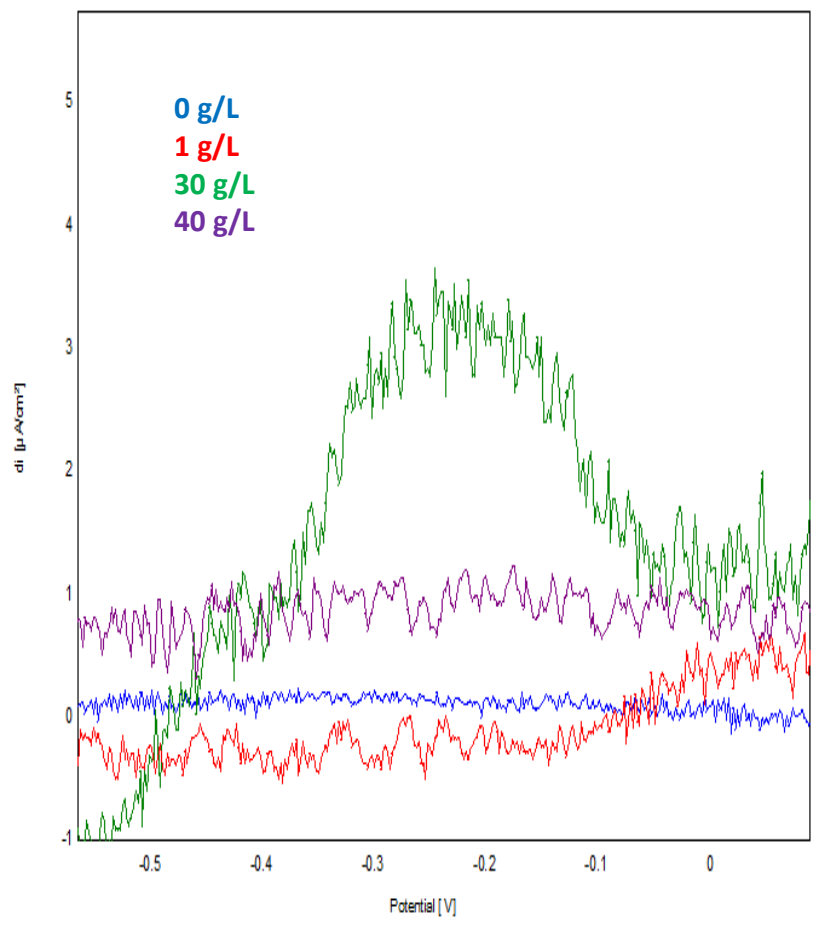

Figure 2: Influence of amoxicillin concentration on peaks current of bacteria in square wave voltammetry at AMX-NPE in $1.0 \mathrm{~mol} \mathrm{~L}^{-1} \mathrm{NaCl}$; the preconcentration time was $10 \mathrm{~min}$.

conditions the proposed sensor showed a typical linear response, which can be expressed according to the following equation:

$\mathrm{OD}=-0.0015 \times \mathrm{CT}+0.8154$

Where CT is contact tie value 


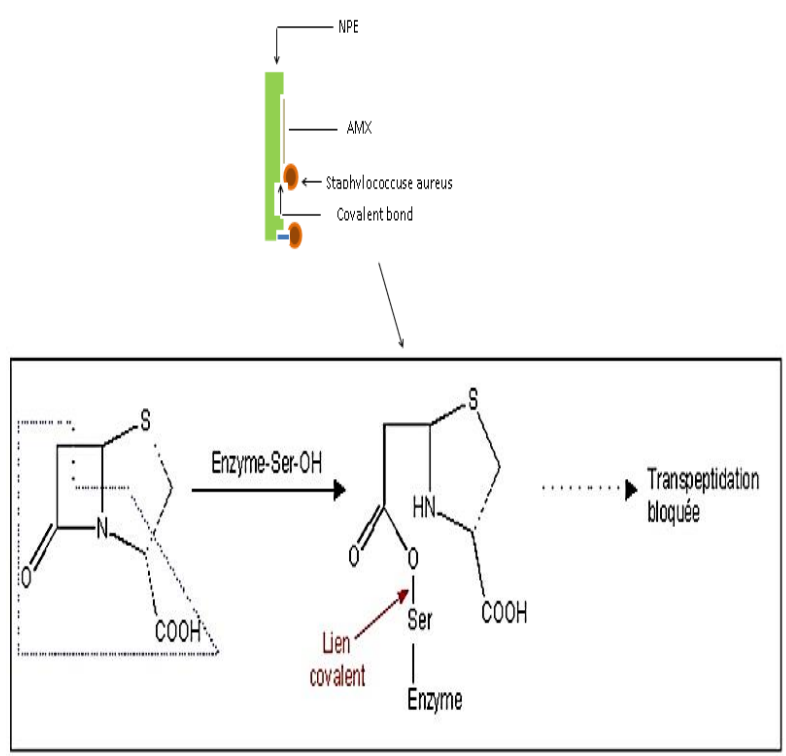

Figure 3: Inhibition of the transpeptidation by beta-lactam [9].

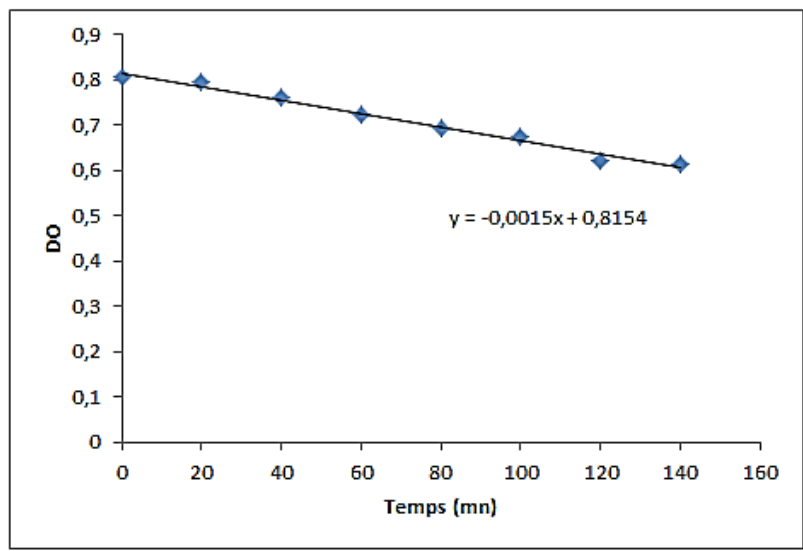

Figure 4: OD dependence of the contact time.

The evolution of the optical density (OD) of the bacteria solution with the contact time was studied. The OD value decreases with the contact time, which leaving argued that the AMX-NPE electrode promotes the extraction of bacteria from the solution. The OD measured by a photometer depends strongly on the contact time (Figure 4 ).

The prepared electrodes were imaged by optical microscopy (Figure 5). The amoxicillin film appear coagulated on natural phosphate. After contact with the bacteria, the film formed by the antibiotic disappears and the electrode surface regains its original appearance. Probably, bacteria adsorb amoxicillin and cause the fragility of the link-antibiotic bacterium (Figure 5).

Figure 6 shows the cyclic voltammograms $(\mathrm{CV})$ curves recorded at prepared electrode after preconcentration in different solution containing bacteria. Electrochemical peak current increases linearly with $\mathrm{OD}$ values (Figure 6).

\section{Conclusion}

A novel Amoxicillin modified natural phosphate paste electrode

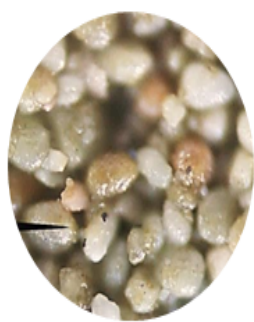

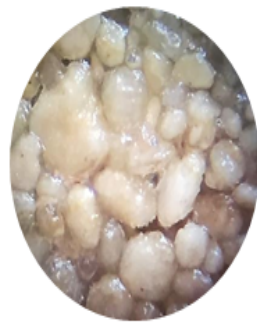

b

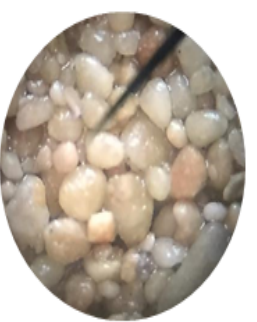

c
Figure 5: Optical microscopy recorded for, a- unmodified NPE, b- AMX-NPE, $\mathrm{C}-\mathrm{AMX}-\mathrm{CPE}$ after preconcentration in the solution containing the bacteria, for $140 \mathrm{~min}$.

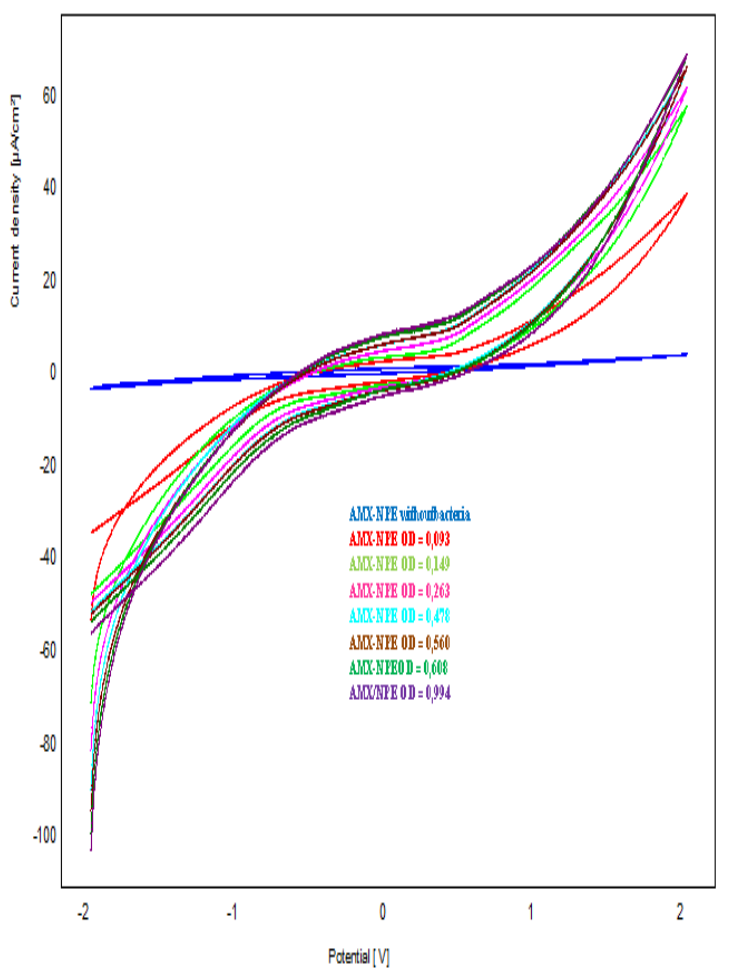

Figure 6: $\mathrm{CVs}$ recorded at $\mathrm{AX}-\mathrm{CPE}$ after preconcentration in different solutions containing bacteria.

was prepared. The modified electrode is highly sensitive towards unmodified natural phosphate paste electrode and provides a rapid response. In the present work the influence of contact time towards peak current response has been investigated by SWV and effect of amount of antibiotic was highlighted to analyze the prepared electrode ability to absorb bacteria. The proposed biosensor exhibited good reproducibility stability and efficiency. AMX-NPE can be able to selectivity detect a living organism such as Staphylococcus aureus. In perspective this work will be chained by the study of interference caused by the presence simultaneously of multiple bacteria and we plan to do an analytical application in conditions close to reality.

\section{References}

1. Bud R (2007) Penicillin: Triumph and tragedy. Norfolk, Angleterre, Oxford University Press p: 340. 
Citation: Bertrand OFAK, Bea B, Belkhouya N, Chtaini A (2016) A Natural Phosphate Electrode Modified with Antibiotic for the Detection of Bacteria. J Biosens Bioelectron 7: 202. doi:10.4172/2155-6210.1000202

2. Blaser M (2011) Antibiotic overuse: Stop the killing of beneficial bacteria. Nature 476: 393-394.

3. Trasande L, Blustein J, Liu M, Corwin E, Cox LM, et al. (2012) Infant antibiotic exposures and early-life body mass. International Journal of Obesity 37: 16-23.

4. Risnes KR, Belanger K, Murk W, Bracken MB (2011) Antibiotic exposure by 6 months and asthma and allergy at 6 years: Findings in a cohort of 1,401US children. Am J Epidemiol 173: 310-318.

5. Tsakok T, McKeever TM, Yeo L, Flohr C (2013) Does early life exposure to antibiotics increase the risk of eczema? A systematic review. $\mathrm{Br} \mathrm{J}$ Dermatol 165: 983-991.

6. Little P, Stuart B, Moore M, Coenen S, Butler CC, et al. (2013) Amoxicillin for acute lower-respiratory-tract infection in primary care when pneumonia is not suspected: a 12-country, randomised, placebo-controlled trial. Lancet Infect Dis 13: 123-129.

7. Natural phosphate comes from CERPHOS, Casablanca, Morocco.

8. EIMhammedi MA, Bakasse M, Chtaini A (2007) Square-Wave Voltammetric Determination of Paraquat at Carbon Paste Electrode Modified with Hydroxyapatite. Electroanalysis 19: 1727-1733.

9. Amlil A, Koffi OFAB, Bile BEA, Chtaini A, Bengourram J, et al. (2016) Electrochemical Biosensor for the Immediate Detection of Bacteria. J BiosensBioelectron 7: 1-4.

10. Bergogne-berezin E, Dellamonica P (1999) Antibiothérapie en pratique clinique. (2ndedn) Masson. 